
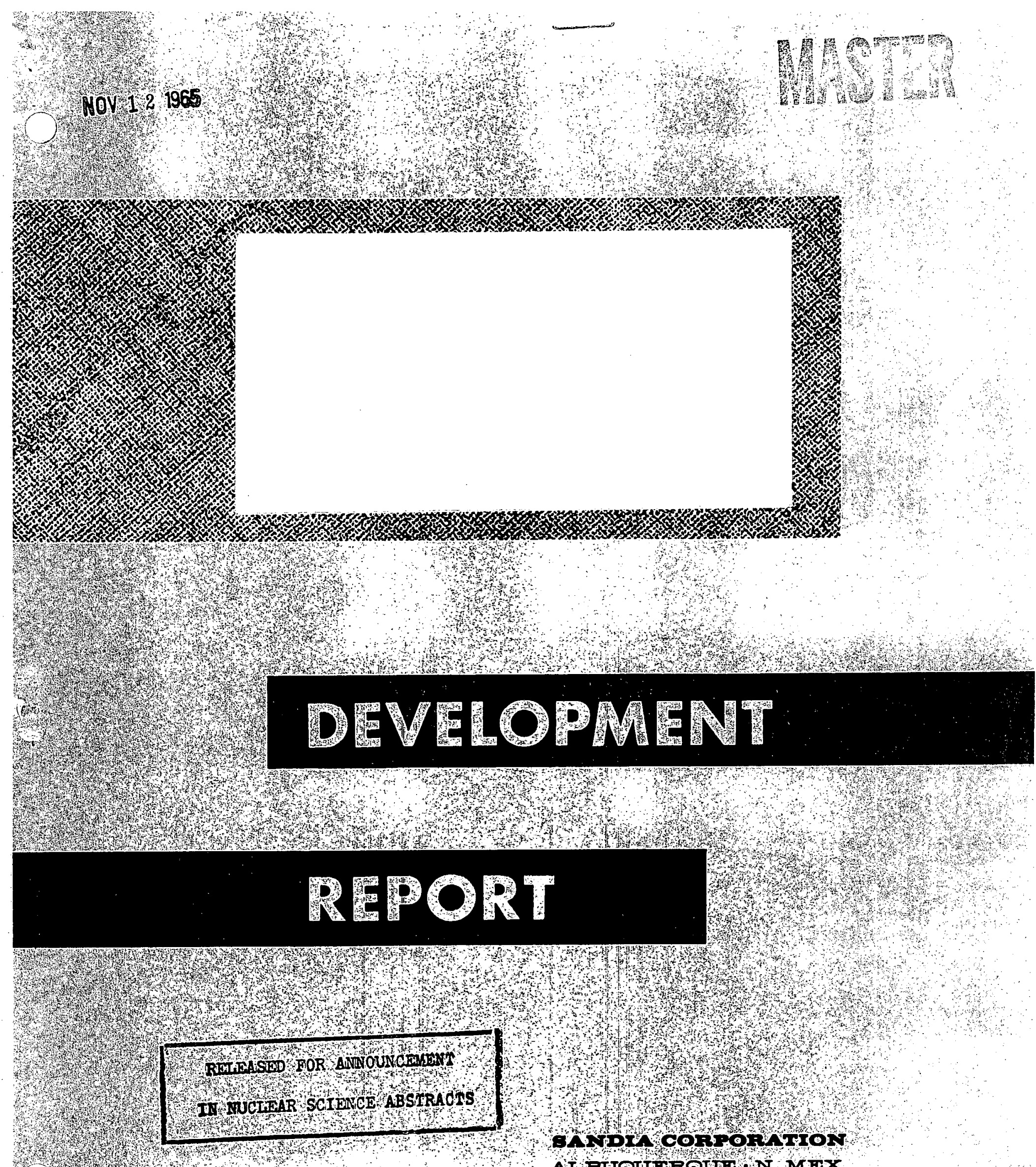

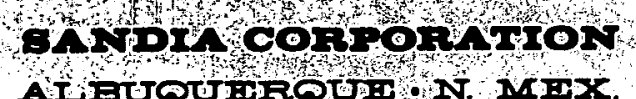




\section{DISCLAIMER}

This report was prepared as an account of work sponsored by an agency of the United States Government. Neither the United States Government nor any agency Thereof, nor any of their employees, makes any warranty, express or implied, or assumes any legal liability or responsibility for the accuracy, completeness, or usefulness of any information, apparatus, product, or process disclosed, or represents that its use would not infringe privately owned rights. Reference herein to any specific commercial product, process, or service by trade name, trademark, manufacturer, or otherwise does not necessarily constitute or imply its endorsement, recommendation, or favoring by the United States Government or any agency thereof. The views and opinions of authors expressed herein do not necessarily state or reflect those of the United States Government or any agency thereof. 


\section{DISCLAIMER}

Portions of this document may be illegible in electronic image products. Images are produced from the best available original document. 


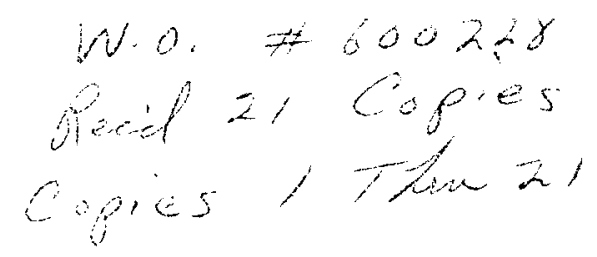

RIMANASED FOR ANNOUNCEMENT

II MUCTAAR SCIENCE ABSTRACTS

\title{
SCDR 58-61 \\ THE MECHANICAL PROPERTIES OF WROUGHT DEPLETED URANIUM AND OF WELDS JOINING THIS MATERIAL
}

\author{
LEGAL NOTICE \\ This report was prepared as an account of Government sponsored work. Neither the United \\ This report was prepared as nor the Commission, nor any person acting on behalf of the Commission:

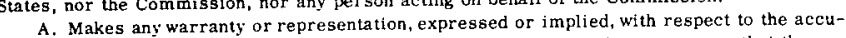 \\ A. Makes any warranty or representation, expressed or implied, with respect to the accu- \\ racy, completeness, or usefulness of the information contained in this report, or that the use \\ privately owned righte: or \\ B. Assumes any liabilitles with respect to the use of, or for damages resulting from the \\ se of any information. apparatus, method, or process disclosed in this report. \\ As used in the above, "person acting on behalf of the Commission" includes any em- \\ ployee or contractor of the Commission, or employee of such contractor, to the extent that \\ ploye commission, or employee of such contractor prepares, \\ dis emas or provides access to, any information pursuant to his employment or contrac \\ with the Commission, or his ernployment with such contractor.
}

V. G. Ne1son, 1121-2

March 1961

Approved by:

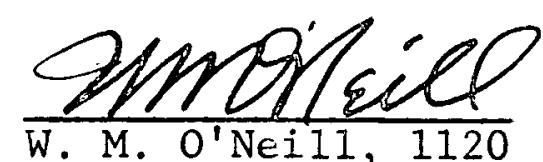

\section{ABSTRACT}

This report describes the test program conducted to establish design allowables for tensile properties in wrought depleted uranium and in welds joining this material. 


\section{ACKNOWLEDGEMENTS}

Appreciation is extended to the Union Carbide Nuclear Company, Y-12 plant, for its fine cooperation in fabricating the plates, welding, and preparation of the specimens; to Organization 1113-1 of Sandia Corporation for testing the specimens; to Organization 2561-3 for the statistical treatment of data; and to Organization 7182-2, particularly Mr. R. I. Dineen, for help in modulus of rupture testing and modulus of elasticity literature search.

\section{DISTRIBUTION:}

J. P. Murray, Union Carbide Nuclear Corporation

C. F. B11d, 1100

W. M. O'Ne111, 1120

H. H. Patterson, 7110

J. W. Jones, 7120

U.S. AEC DTIE \& H.F. CARROLL

R. G. Hogan, 7122

R. S. Wilson, 7140

S. A. Moore, 7180

R. T. Othmer, 7182-1

M. W. Causey, $7182-2$

B. G. Prentice, 7182-3

L. E. Davies, 8110

L. Gutierrez, 8140

R. K. Sme1tzer, 3421-3

W. F. Carstens, 3423

Distribution, 3466-1

R.K.Smeltzer, $3421-3$ (1)

$$
\begin{aligned}
& 1523 \\
& 1121-2
\end{aligned}
$$

$\angle A S L(1)$
$\arg .1114$
REPRODUCTION PERMISSION

This report is not to be reproduced, in whole or in part, without written permission of the manager of the originating department. 
Issued by Sandia Corporation,

a prime contractor to the

United States Atomic Energy Commission

\section{LEGA NOTICE}

This report was prepared as an account of Government sponsored work. Neither the United States, nor the Commission, nor any person acting on behalf of the Commission:

A. Makes any warranty or representation, expressed or implied, with respect to the accuracy, completeness, or userulness of the information contained in this report, or that the use of any information, apparatus, method, or process disclosed in this report may not infringe privately owned rights; or

B. Assumes any liabllities with respect to the use of, or for damages resulting from the use of any information, apparatus, method, or process disclosed in this report.

As used in the above, "person acting on behalf of the Commission" includes any employee or contractor of the Commission, or employee of such contractor, to the extent that such employee or contractor of the Commission, or employee of such contractor prepares, disseminates, or provides access to, any information pursuant to his employment or contract with the Commission, or his employment with such contractor. 
ACKNOWLEDGEMENTS

Introduction

Material

Fabrication Procedure

Tensile Properties

Tensile Testing

Tensile Data

Discussion of the Tensile Data

Effect of Impurities on Tensile Properties

Impact Properties

Modulus of Rupture of Butt-Welded Uranium Bars

Fillet Weld Shear Values

Meta1lography

Conclusions

APPENDIX A - LIST OF REFERENCES

APPENDIX B - TABULATION OF DATA

\section{LIST OF ILLUSTRATIONS}

1 Stress-Strain Curve

2 Test Bars

3 Loading Systems for Bend Bar Tests

$4 \quad$ Fillet Weld Test Specimen $\quad 15$

5 Microstructure of Depleted Uranium, Plate 1

6 Microstructure of Depleted Uranium, Plate 2

$7 \quad$ Weld Structures 


\section{THE MECHANICAL PROPERTIES OF WROUGHT \\ DEPLETED URANIUM AND OF WELDS \\ JOINING THIS MATERIAL}

\section{Introduction}

A test program was conducted to establish design allowables for tensile properties in wrought depleted uranium and in welds joining this material. These allowables are the lower limit that will, at 95 percent confidence, have 95 percent of all values equal to or above the limit. Typical values of charpy impact were determined for the uxanium and the butt welds. Free bend bars were cut across the weld joints and tested to learn of the behavior of welds in bending and to determine the modulus of rupture in bending. Typical values for longitudinal and transverse shear in fillet welds were determined.

This report describes the test program and recommends the design allowables for tensile properties in wrought depleted uranium and for welds used in joining this material.

Materia1

Two rolled plates of depleted uranium furnished by UCNC-Y12 were used in this program, and the purity levels of the two plates were:

Element

$\mathrm{C}$

$\mathrm{Fe}$

Total $\mathrm{Fe}, \mathrm{Ni}, \mathrm{Cr}$

Total all others
Plate 1

126 ppm

$78 \mathrm{ppm}$

101 ppm

383 ppm
Plate 2

401 ppm

$270 \mathrm{ppm}$

$351 \mathrm{ppm}$

802 ppm 
Fabrication Procedure

The plate material had been subjected to the following treatment and rolling schedule by Y12:

1. $5 \times 24 \times 24-1$ nch ingots were soaked for 14 hours in a salt bath at temperatures of $1150^{\circ} \mathrm{F}$ to $1170^{\circ} \mathrm{F}$.

2. Plate 1 was rolled to a thickness of 3 inches, then turned 90 degrees and rolled to $0.75 \times 52 \times 74$ inches. Plate 2 was rolled to a thickness of 3 inches, turned 90 degrees and rolled to a 1.5-inch thickness, then turned 90 degrees and rolled to $0.75 \times 45 \times 87$ inches.

3. Rolling temperatures for Plate 1 were $1080^{\circ} \mathrm{F}$ at the start, $910^{\circ} \mathrm{F}$ at $3-$ inch thickness, and $790^{\circ} \mathrm{F}$ at the finish. Rolling temperatures for Plate 2 were $1080^{\circ} \mathrm{F}$ at the start, $1000^{\circ}$ at 3 -inch thickness, $820^{\circ} \mathrm{F}$ at 1.5-inch thickness, and $750^{\circ} \mathrm{F}$ at the finish.

4. Each plate was alpha annealed at $1130^{\circ}$ to $1150^{\circ} \mathrm{F}$ for 15 minutes in a liquid salt bath.

The plates were cut, given a $37^{\circ} 30^{\prime}$ chamfer, leaving a $1 / 16$-inch land and welded so that all weld beads were normal to the direction of rolling. The following procedure was used:

1. Welding filler metal was sheared irito strips $5 / 32 \times 3 / 16$ inch from two batches of sheet made from two heats having the following analysis:

\begin{tabular}{|c|c|c|}
\hline Element & Heat 3961 & Heat 3963 \\
\hline C & $240 \mathrm{ppm}$ & $131 \mathrm{ppm}$ \\
\hline $\mathrm{Fe}$ & $120 \mathrm{ppm}$ & $70 \mathrm{ppr}$ \\
\hline Total Fe, Ni, Cr & $120 \mathrm{ppm}$ & $120 \mathrm{ppm}$ \\
\hline Total all others & $146 \mathrm{ppm}$ & $217 \mathrm{ppr}$ \\
\hline
\end{tabular}

Al1 the strips were mixed together and no attempt was made to weld either plate with a particular heat of filler rod. 
2. Welding was done by the inert gas shielded tungsten arc method, using 99.99 percent pure helium as the arc shield.

3. Butt welds were single vee, 75 degree included angle, 1/16-inch 1and. A copper backup strip having a groove 1/4-inch wide and 1/16-inch deep was used. All passes were made using DC straight polarity. The root pass was made at 190 amperes and 25 volts. Succeeding passes were made at 220 amperes and 25 volts, the butt welds being completed in from 9 to 13 passes.

4. The transverse fillet welds were made in three passes, the first at 190 amperes and 25 volts, and the remaining passes at 220 amperes and 25 volts. The longitudinal fillet welds were made in one pass at 165 amperes and 20 volts. No post weld heat treatments were employed.

A11 welds were subjected to radiographic examination and were found to be acceptable with the possible exceptions of the transverse fillet weld shear specimens made from Plate 2. Radiographs were judged in accordance with the UCNC Standard Y-ES 9.3-52. This standard is more rigid than the ASTM Code, Section VIII, concerning porosity and inclusions, but does allow some cracks. No cracks were detected by radiography or in the subsequent testing.

Tensile Properties

\section{Tensile Testing}

The test plates were cut up and machined by Y-12 to 2-inch gage length, 0.505-inch diameter, and 1.75-inch gage length, 0.357 -inch diameter test bars. Tensile testing was done in Sandia Laboratory Section 1113-1 on a Universal testing machine at the temperatures of interest using a strain rate somewhat uncertain, the only known factor being the cross-head travel of 0.1 inch per minute throughout the test. The modulus was derived graphically from the stress-strain curve (see Figure 1 ) and the reported yield strength is the 0.2 percent offset intersection. The yield and ultimate strength are calculated on the basis of the original cross-sectional area. 


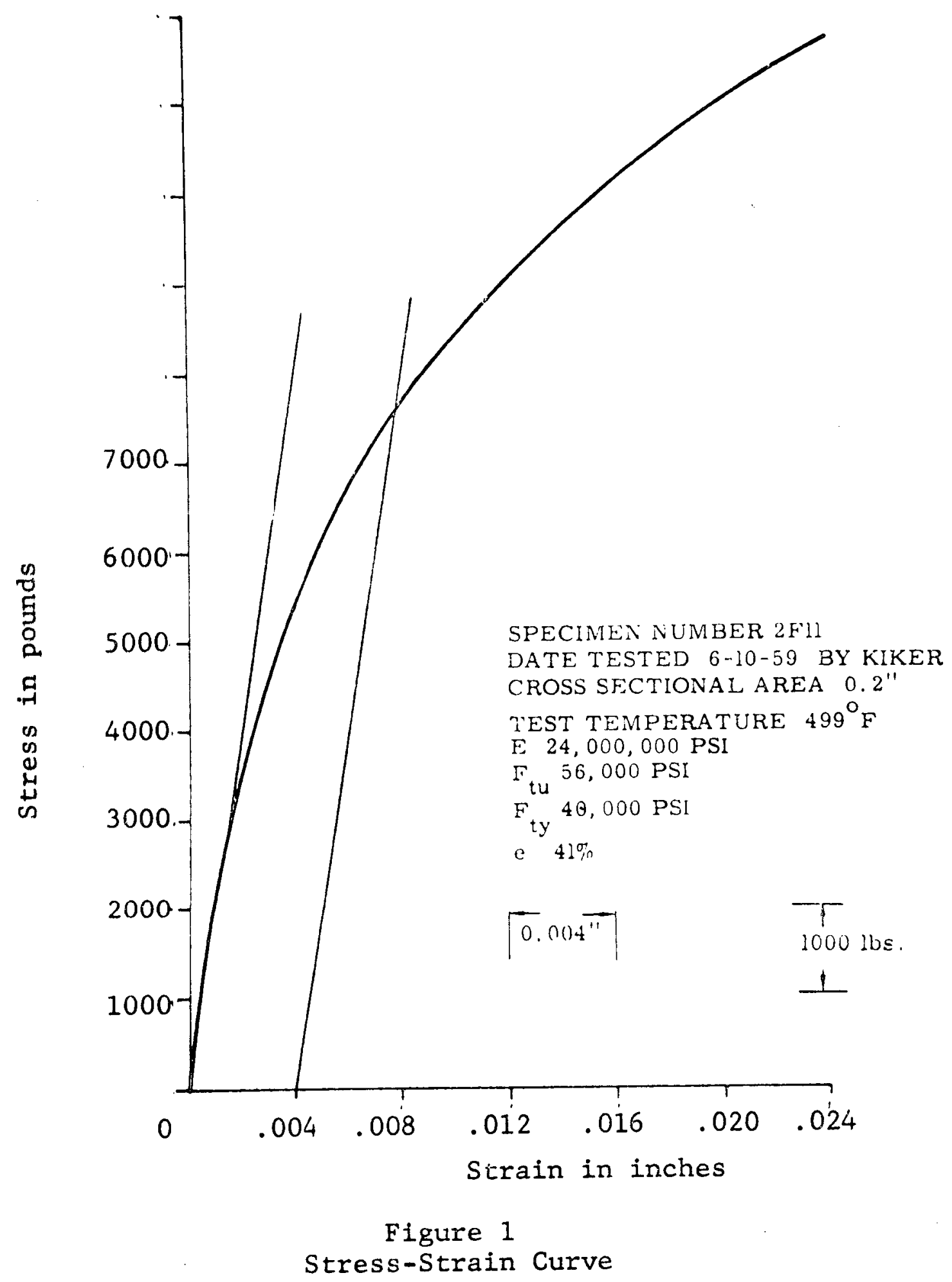


The extensometer used was the microformer type with a magnification of 250 to 1 . The elongation was determined by measuring the distance between gage marks after rupture, using a divider.

\section{Tensile Data}

The tensile property data were given a statistical treatment by Section 2561-3, Sandia Laboratory, to obtain the lower limit at a confidence level such that 95 percent of the time 95 percent of al1 values will be the lower limit or above. The assumption is made that the data has normal distribution. This can neither be proved nor disproved with the quantity of data available. The degree of confidence actually present in the results is wholly dependent on the accuracy of this assumption. The $\mathrm{K}$ factors used for sigma for the number of samples involved were:

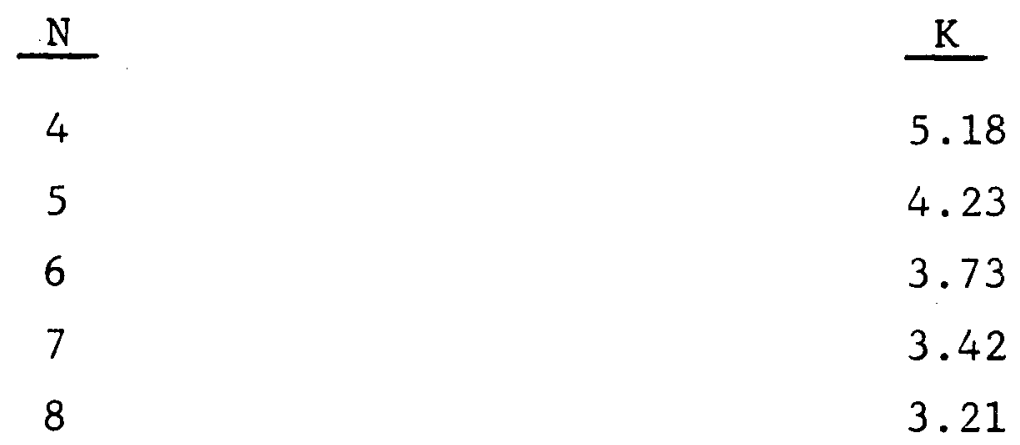

These factors were taken from Lieberman and Resnikoff.

Specimens that broke in the radius or in the threads were considered no test. Those that broke in the 0.505 straight section but outside the gage marks were used for all properties except the elongation. Occasionally there was malfunction of the extensometer because of interference of its extension rods with the furnace or cold box, resulting in no curve.

The tensile data are tabulated in Table I, Appendix B; graphic summaries are also presented in Appendix B, Figures B-1 through B-4. 
Generally, the tensile ultimate and tensile yield strengths were lower and elongation higher in Plate 1 than in Plate 2 which may be attributed to the higher purity in Plate 1 . This trend occurred in welded joints in the two plates. In bars cut across weld joints it is felt that yield strength is of value to the designer, whereas elongation probably is of little value because of the composite structure. In weld joints tested at elevated temperature, practically all the elongation had taken place in the parent metal (see E; Figure 2). The all weld metal bars showed a higher yield strength, lower ultimate strength, and lower elongation than plate material tested at room temperature.

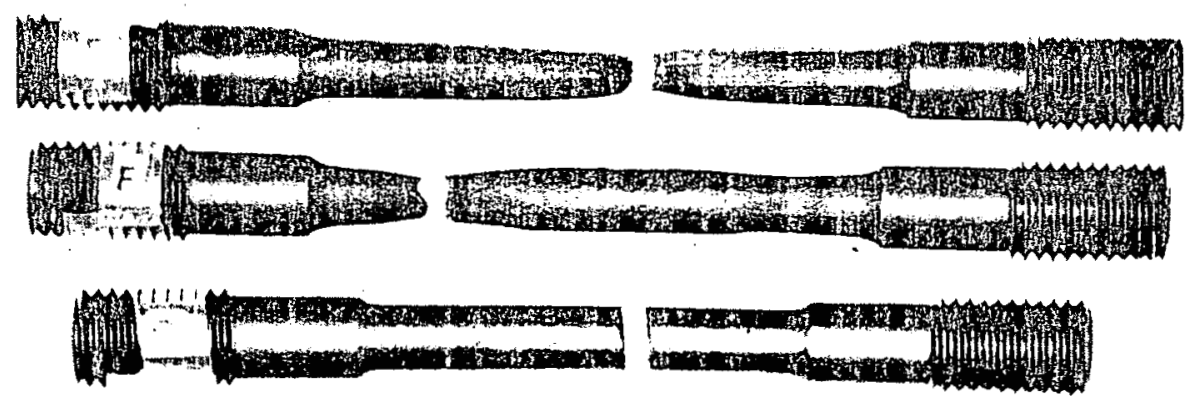

Figure 2. Test Bars

The modulus values showed considerable scatter, a partial explanation being the difficulty in fitting a modulus line to the stressstrain curve. The error tends to be toward a lower modulus value. Hueschen and Pitt of the Hanford Atomic Products Operations reported an average modulus, graphically determined, of $23 \times 10^{6}$. Their moduli at elevated temperatures correlate fairly well with those of this report. From a curve of modulus versus temperature determined by Mayfield, Chiswick and Mackerey of Argonne National Laboratories, the oom temperature modulus is $22.75 \times 10^{6}$, again graphically determined. 
Investigators using the sonic method (longitudinal wave velocities) report values up to $30 \times 10^{6}$. Reynolds of Knolls Atomic Power Laboratory reports a sonically measured modulus of $25.5 \times 10^{6}$, an average of 12 samples each having measurements in three mutually perpendicular directions. Bernard and Coureau show that sonically determined moduli are fairly constant for cast, extruded, or rolled uranium. Grain orientation appears to have some effect on the sonic modulus. This effect can be reduced by working and heat treatment. As indicated in the work of Hueschen and Pitt, the graphically determined moduli do not vary greatly for uranium with impurity limits of 126 to $730 \mathrm{ppm}$ carbon and 50 to $270 \mathrm{ppm}$ of iron. It does seem unrealistic to use lower limits of the moduli since it appears that the modulus is not entirely dependent on anisotrophy or previous metallurgical history. A study should be made of the distribution curve for a large number of samples, using better methods to establish the modulus line. The recommended value to use for the modulus in tension is $23 \times 10^{6}$.

Effect of Impurities on Tensile Properties

The impurity level of the depleted uranium has a significant effect on the tensile properties, the carbon content having the greatest effect. From data Union Carbide Nuclear Company, Y-12 Plant, collected over a period of twelve months, a distribution curve for carbon content for all heats of "Tuballoy" that produced rolled and formed products shows the mode of the distribution curve to be about $250 \mathrm{ppm}$ carbon. Within the two sigma distribution limits, the carbon content varies between $100 \mathrm{ppm}$ and $450 \mathrm{ppm}$ covering about 90 percent of all heats. Plates 1 and 2 of this report are approximately at these two sigma distribution points so that the data here presented cover about 90 percent of UCNC heats.

Impact Properties

Impact testing was done using charpy bars per ASTM E23-47T and on a standard pendulum-type tester using the 260-foot-pound range. A11 impact data were generated at room temperature and the data tabulated in Table II (see Appendix B). 
The impact properties in the weld heat affected zone are the 1owest. No significant differences occur between weld metal and parent metal. A large increase in toughness occurred in the Plate 2 material when the notch was transverse to rolling.

Modulus of Rupture of Butt-Welded Uranium Bars

Two types of tests were performed to determine the modulus of rupture in bending of butt-welded uranium bars. In the first series of tests, pure bending moment was applied to the center portion of the specimen, using a two-point loading system. The second series of tests employed a concentrated load at the center of the specimen, producing both shear and moment in the weld. Both test systems are illustrated in Figure 3.

The specimens tested were taken from two different plates and were tested in two orientations: with the face of the weld in tension and with the face of the weld in compression.

In the first series of tests, two bars from the same plate were . tested in pure bending using both orientations. SR4 strain gage raeasurements indicated that the strains were largest in the parent metal, decreased in the heat affected zone, and were smallest in the weld.

The bar orfented with the face of the weld on the compression side experienced the larger deflections of the two specimens. Load was applied to both specimens until the deflections became so large that a further Increase in load was impossible. No failure occurred in efther case with the total angle change between the tangents at the ends of the bars being about 65 degrees.

Four bars were tested in the second series of tests, using a single point loading arrangement. Three of the specimens were from Plate 2 while the fourth specimen was taken from Plate 1 . The deflections in this series of tests were considerably less than in the twopoint loading setup. This difference in deflection is due in part to the method of loading. By assuming elastic conditions, the deflection in the two-point loading setup is about 1.34 times the deflection in the single point loading arrangement for the same moment. The specimen from Plate 1 experienced a total angle change of 35 degrees at rupture, while the specimens from Plate 2 had a maximum total angle change of 20 degrees at rupture. 

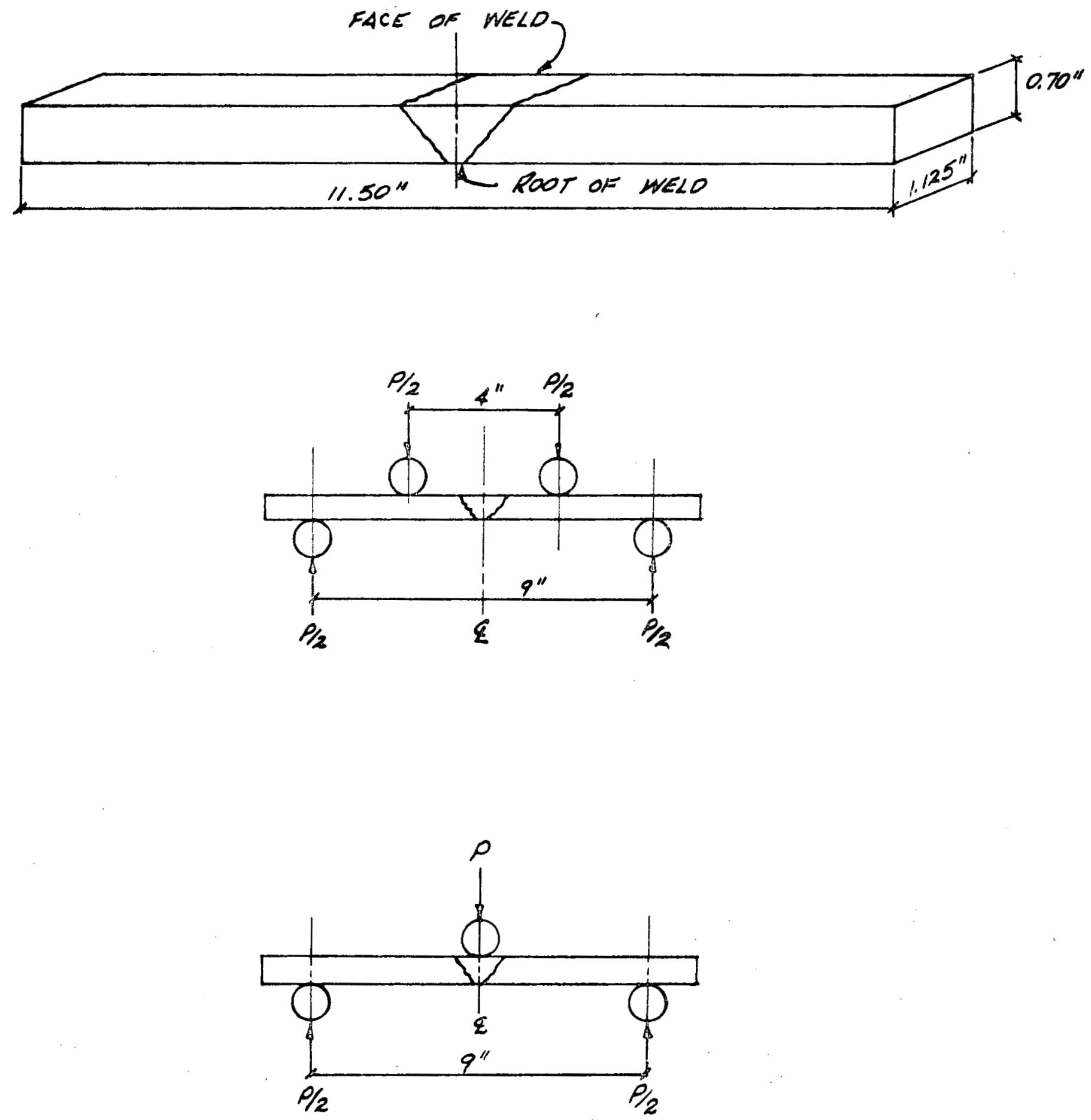

Figure 3

Loading Systems for Bend Bar Tests 
Fallure in three of the bars tested in the second series occurred in the center of the weld; the fourth bar failed in the heat affected zone. The modulus of rupture ranged from 159,000 to 180,000 psi. Since the modulus of rupture is dependent both on the size and shape of the cross section, the above values should be used with caution.

Fillet Weld Shear Values

Specimens for the shear values of fillet welds were made according to the American Welding Society requirements. Pieces were cut from the plate so that the direction of rolling in the pieces making up the specimen was along the long axis of the specimen. Testing was done at $76^{\circ} \mathrm{F}$, using a crosshead speed of 0.1 inch per minute. The data are tabulated in Table III, Appendix B. The shear strength was calculated from the mean load on the theoretical throat distance for the specified fillet weld size.

Plate 1 had higher shear values than Plate 2, and the longitudinal values in both plates were higher than transverse shear. Fractures in the specimens occurred mainly in the welds but did, in - various instances, occur in both welds and the butt strip and in the heavier plate (see Figure 4).

\section{Metallography}

Metallographic samples from both plates were cut from the threaded ends of broken tensile bars and the vise clamped ends of charpy bars. The grain size of both plates varied from about 40 to 80 microns. Grain size of the weld metal was about 150 microns. Both plates had a great number of fine inclusions and a sparse scattering of large inclusions. Anisotrophy was more pronounced in Plate 2 than in Plate 1 . The dark lines traversing the grains were present in samples from the plates as well as from the broken specimens. The light spots are the fine inclusions. The metallographic samples were electropolished (using chrome-acetic acid); viewed, and photographed with polarized light (see Figures 5, 6, and 7). 

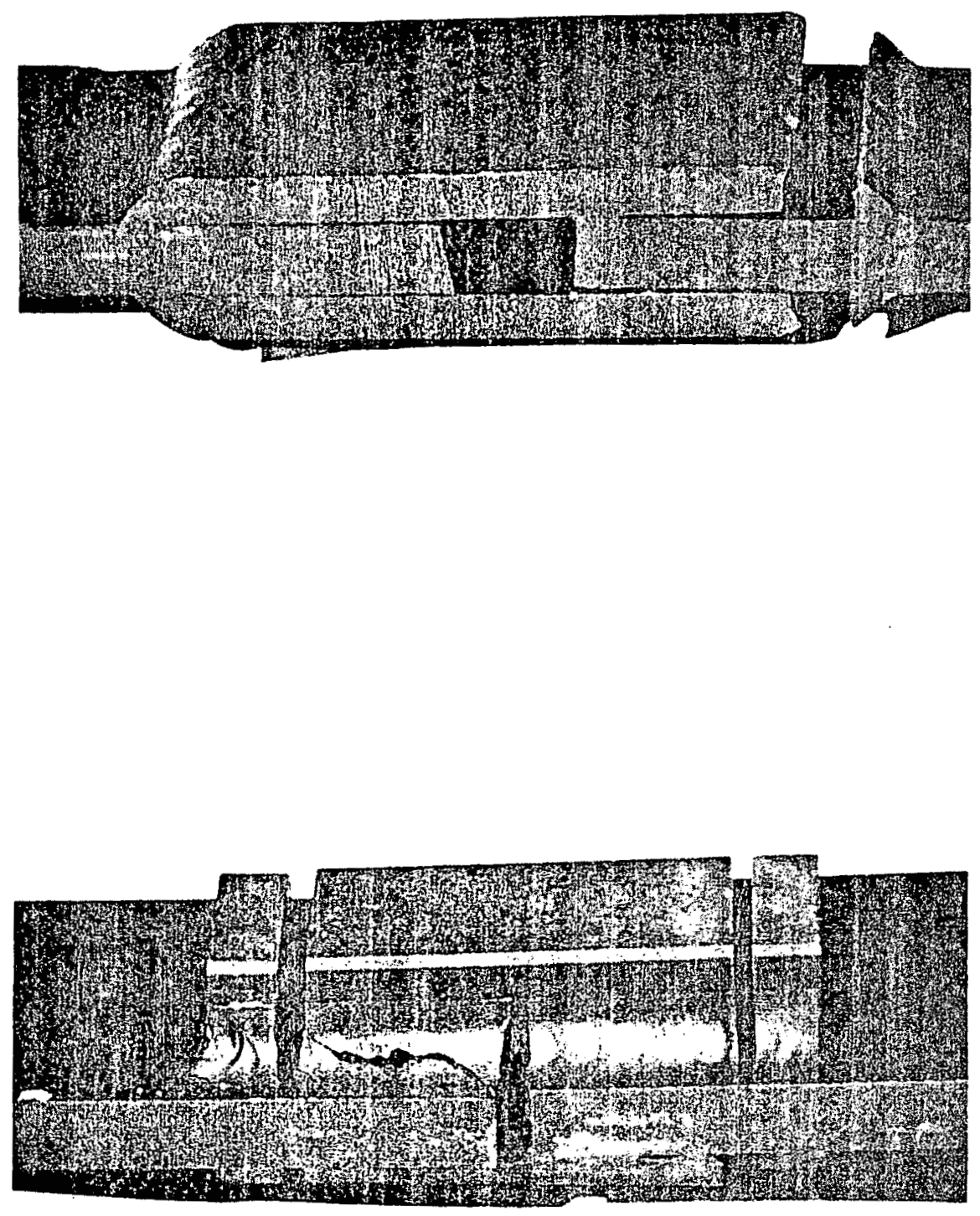

Figure 4

Fillet Weld Test Specimen 


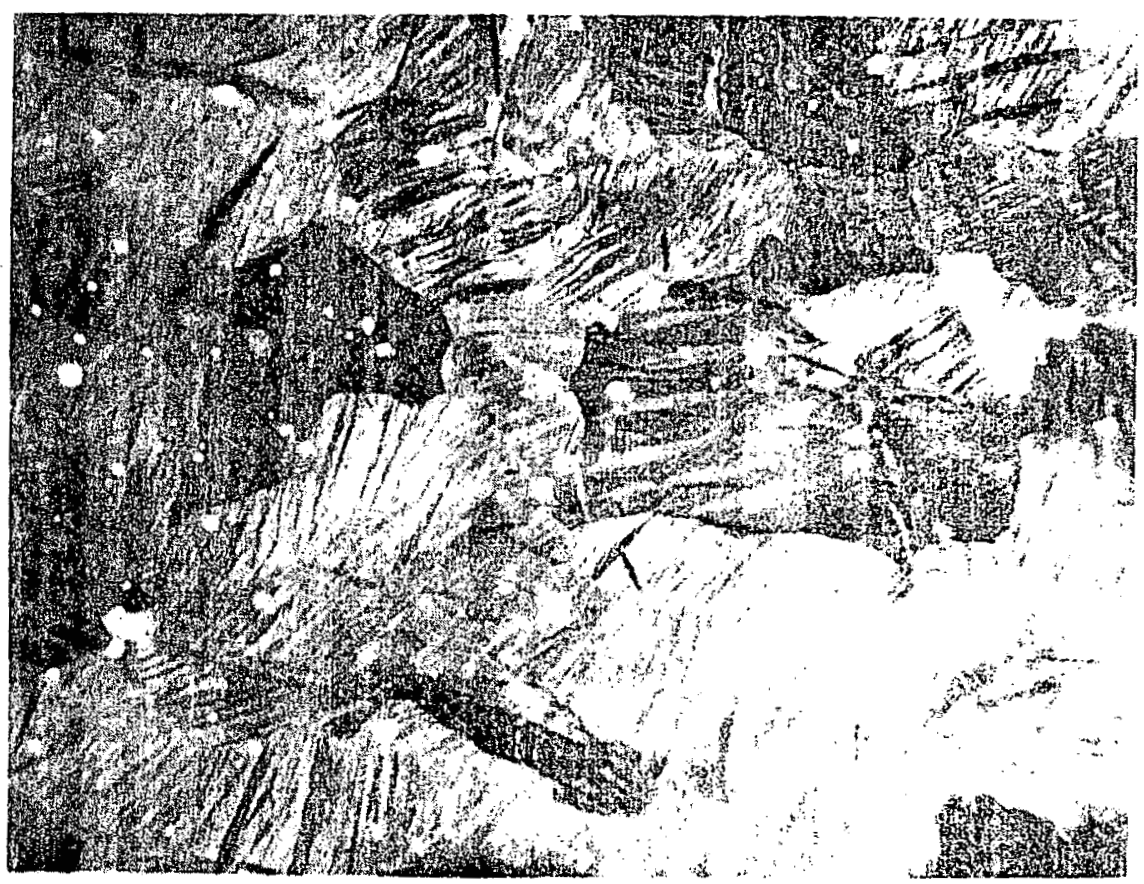

Longitudinal to Rolling, 390x

Transverse to

Rol1ing, 390x

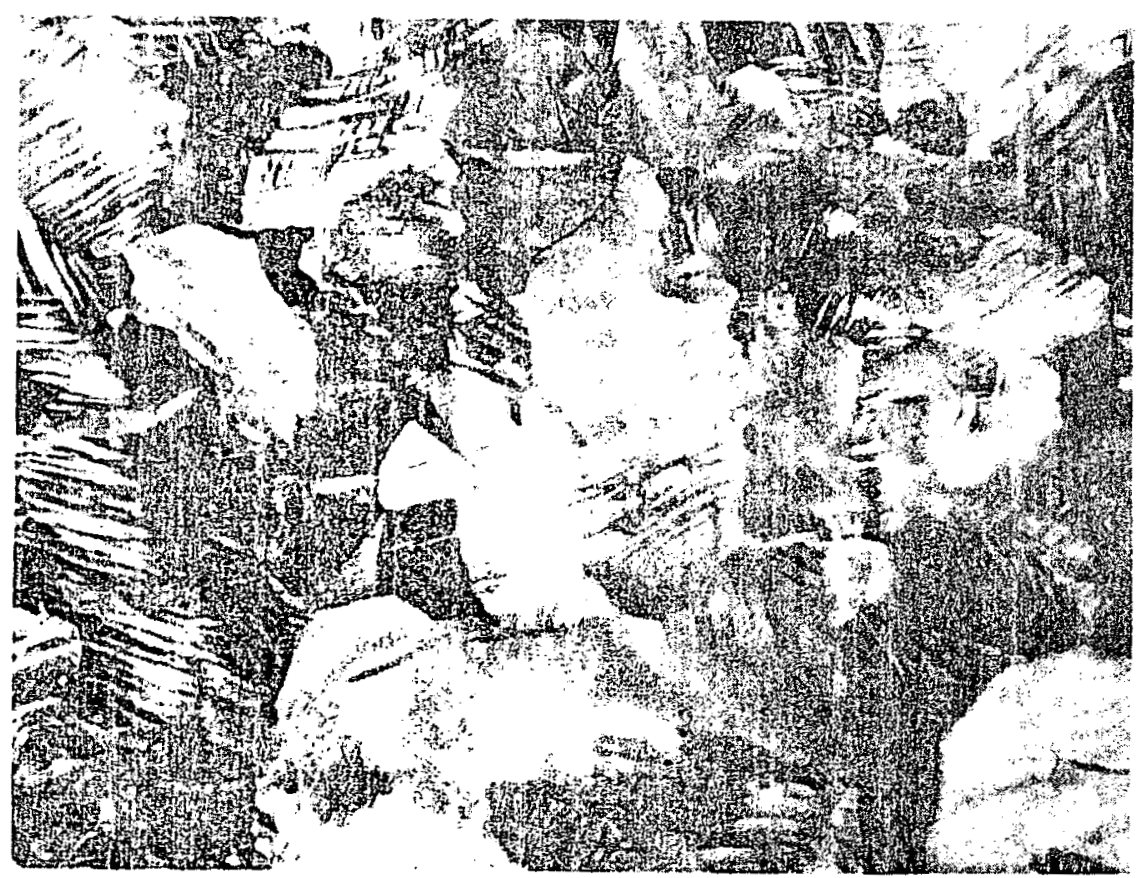

Figure 5

Mjcrostructure of Depleted Uranium, Plate 1 


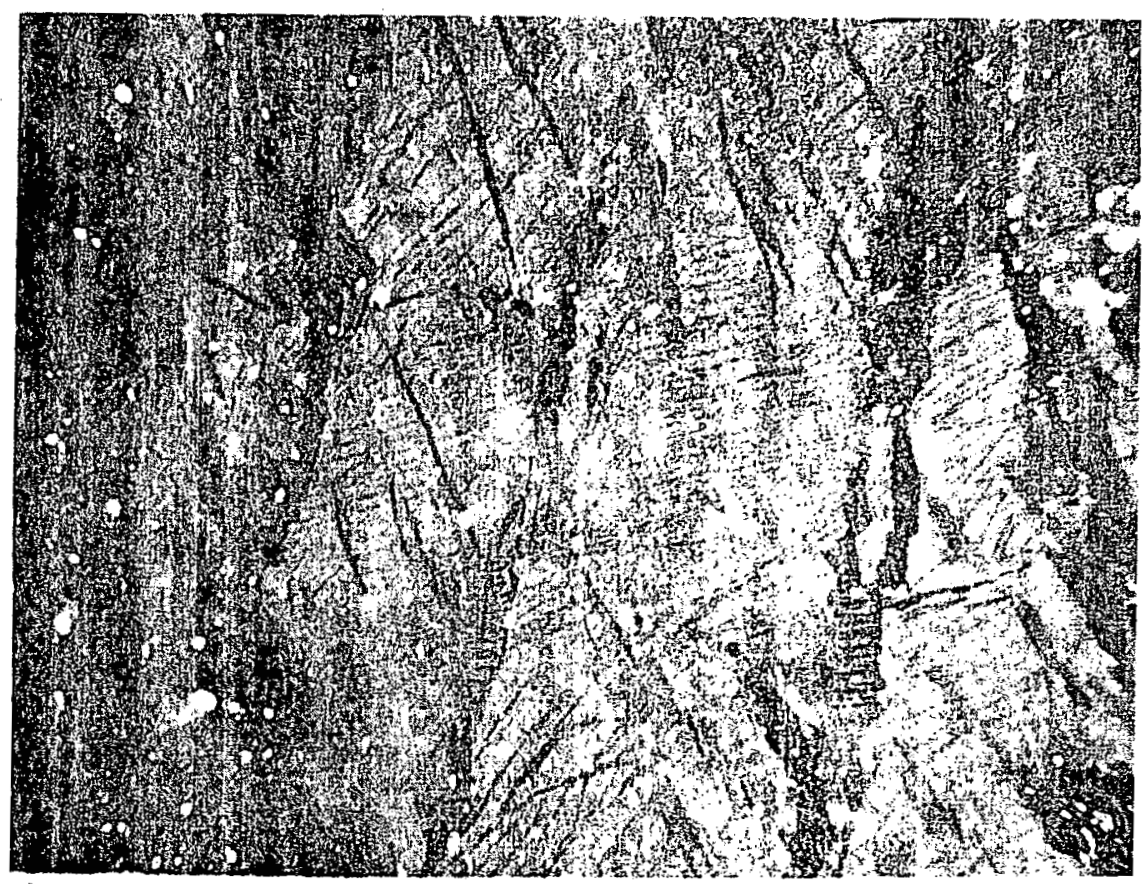

Longitudinal to Rolling, 390x

Transverse to Rolling, 390x

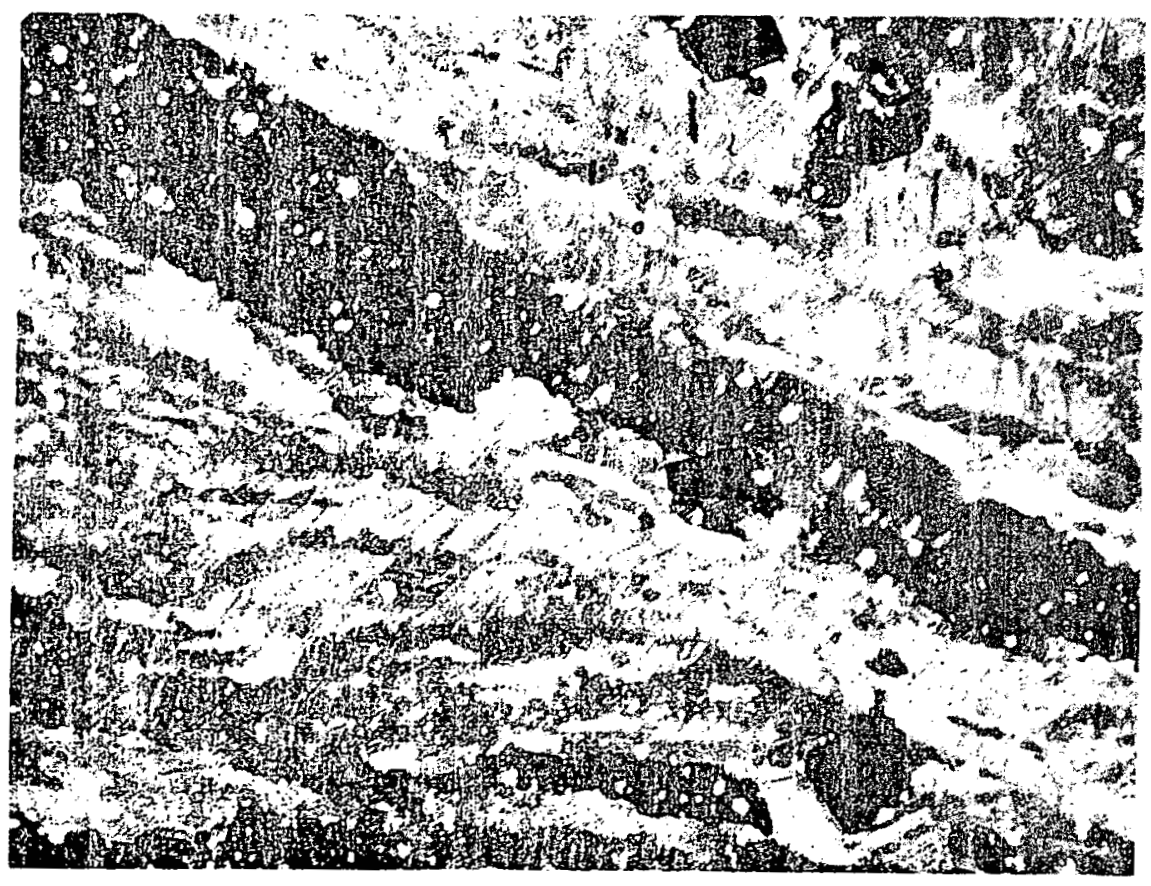

Figure 6

Microstructure of Depleted Uranium, Plate 2 

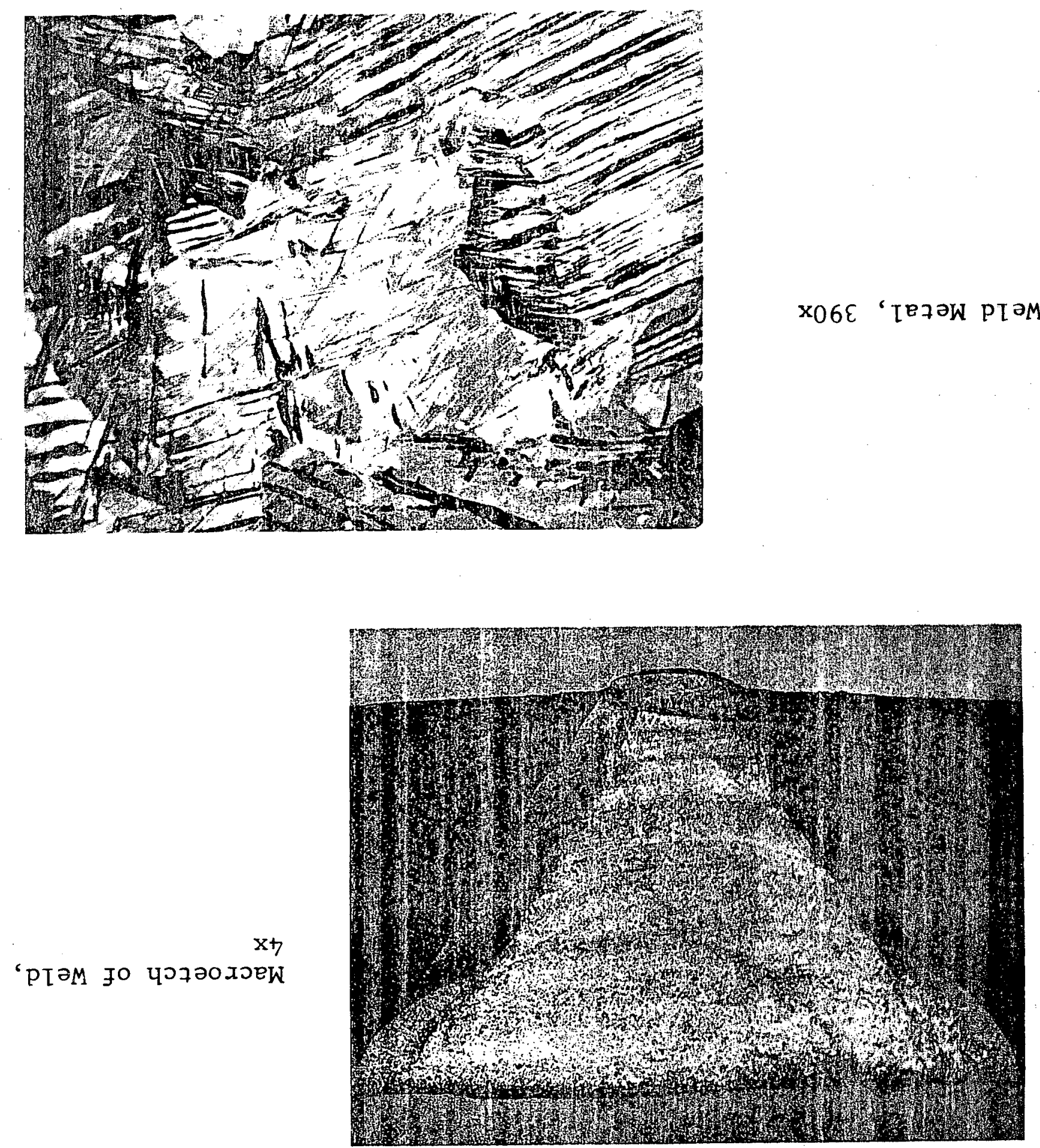


\section{Conclusions}

The lower value of the appropriate lower limit of the two plates should be used as the design allowable for that property, in the temperature range of interest. The recommended value for modulus in tension is $23 \times 10^{6}$. Charpy impact values averaged $14.0 \mathrm{ft}-1 \mathrm{bs}$ for the plates in both transverse and longitudinal to rolling directions. In the weld joint the heat-affected zone had charpy values of $9.7 \mathrm{ft}-$ 1.bs. The modulus of rupture in welds is $170,000 \mathrm{psi}$ for the crosssection tested. Longitudinal shear in fillet welds is 61,000 psi and transverse shear is 51,500 psi. 


\section{APPENDIX A}

\section{LIST OF REFERENCES}

"Mechanical Properties of Rolled Uranium Rods", by R. M. Mayfield, H. H. Chiswick, and R. E. Macherey, Argonne National Laboratory, ANL-5296.

"Inttial Investigation of the Mechanical Properties of Uranium at Elevated Temperatures", by R. E. Hueschen, C. H. Pitt, Hanford Works, Richland, Washington, December 2, 1952, HW-26426.

"Mechanical Behavior of Uranium", by J. Bernard, G. Coureau. CEA 693 (1957). (Translated from French) General Electric Company, Hanford Atomic Products Operation, Document No. HW-TR-9.

"New Elastic Constants of Some Meta1s", by Myron B. Reynolds. Knolls Atomic Power Laboratory, Schenectady; New York, May 1, 1951, KAPL-576. 
APPENDIX B

TABULATION OF DATA 
PLATE 2

\begin{tabular}{|c|c|c|c|c|c|c|c|c|c|}
\hline & & $\begin{array}{l}\text { Tensile } \\
\text { yield }\end{array}$ & $\begin{array}{l}\text { Tensile } \\
\text { uitimate }\end{array}$ & $\begin{array}{l}\text { Elongacion, } \\
\text { in two inches }\end{array}$ & $\begin{array}{l}\text { Modul } \\
\times 10\end{array}$ & $\begin{array}{l}\text { Tensile } \\
\text { yizid }\end{array}$ & $\begin{array}{l}\text { Tensile } \\
\text { ultimate }\end{array}$ & $\begin{array}{l}\text { Elongation, \% } \\
\text { in two inches }\end{array}$ & $\begin{array}{l}\text { Moduigs } \\
\times 10^{6}\end{array}$ \\
\hline Plate material & Position in plate & $\dot{E}$ & $\varepsilon$ & E & $\Xi$ & $\mathrm{C}$ & $c$ & c & $c(5)$ \\
\hline Trznsuerso to rolling & Tempetature of test & $-65^{*}=$ & $-6: " \mathrm{~F}$ & $-65^{\circ} \mathrm{5}$ & $-6 \Xi^{\circ} \mathrm{F}$ & $-\epsilon \Sigma^{\circ} E$ & $-65=5$ & $-65^{\circ}=$ & $-65=-$ \\
\hline \multirow[t]{6}{*}{ Lowi tergerature } & Number of samples & $2(1)$ & 3 & 2 & 2 & $3(1)$ & 4 & 3 & 3 \\
\hline & Minimun value & 45500 & $97000-$ & 3.0 & 21.00 & $49200-$ & $104100-$ & 2.0 & 20.00 \\
\hline & Maximm value & 49000 & 98500 & 4.0 & 22.50 & 51500 & 114000 & 2.5 & 24.25 \\
\hline & Mean & 47250 & 98000 & 3.50 & 21.75 & 50650 & 109400 & 2.30 & 22.90 \\
\hline & Standard deviation & $-\cdot$ & $\cdots$ & -- & & $-\cdot$ & 5000 & $-\cdots$ & \\
\hline & Lower limit & $\cdots(4)$ & $\cdots$ & $\cdots$ & & --- & 83500 & --- & \\
\hline Plate naterial & Position in plate & $F$ & $F$ & $\mathrm{~F}$, & $\mathrm{F}$ & $\mathrm{F}$ & $\mathrm{F}$ & F & $\mathrm{F}$ \\
\hline Parailel to rolling & Temperature of test & $-65=\mathrm{F}$ & $-65^{\circ} \mathrm{r}$ & $-6 j=\mathrm{F}$ & $-65^{\circ} \ddot{r}$ & $-65^{\mathrm{c}} \mathrm{F}$ & $-65^{\circ} \mathrm{F}$ & $-65^{\circ} \mathrm{F}$ & $-65^{\circ} \mathrm{F}$ \\
\hline \multirow[t]{6}{*}{ Low temperature } & Number of samples & 8 & 8 & 8 & 8 & 8 & 8 & 8 & 8 \\
\hline & Minimum value & $35500-$ & $97000-$ & 5.0 & 20.50 & $37000-$ & $114000-$ & 3.0 & 19.20 \\
\hline & Maximum value & 49200 & 99600 & 6.0 & 23.00 & 41000 & 118000 & 4.0 & 23.50 \\
\hline & Mean & 41150 & 98350 & 5.75 & 21.80 & 39400 & 116400 & 3.25 & 21.60 \\
\hline & Standard deviation & 5900 & 995 & 0.45 & & 1250 & 1060 & 0.45 & \\
\hline & Lower limit & 22200 & 95150 & 4.30 & & 35400 & 113000 & 1.80 & \\
\hline Weld joint & Position in plate & $\mathrm{J}$ & $\mathrm{J}$ & $\mathrm{J}$ & $\mathrm{J}$ & B & B & B & B \\
\hline Bars cut & Temperature of test & $-65^{\circ} \bar{r}$ & $-65^{\circ} \mathrm{F}$ & $-65^{\circ} \mathrm{F}$ & $-65^{\circ} \mathrm{F}$ & $-65^{\circ} \mathrm{F}$ & $-65^{\circ} \mathrm{F}$ & $-65^{\circ} \mathrm{F}$ & $-65^{\circ} \mathrm{F}$ \\
\hline \multirow[t]{6}{*}{ Transverse to joint } & Number of samples & $5(2)$ & 8 & 8 & 5 & 7 & 7 & 7 & 7 \\
\hline & Minimum value & $42000-$ & $76400-$ & 2.0 & 17.00 & $47500-$ & $95000-$ & 2.0 & 20.50 \\
\hline & Maximum value & 45200 & 81600 & 3.5 & 21.65 & 50700 & 103000 & 2.5 & 23.50 \\
\hline & Mean & 43400 & 79200 & 2.60 & 19.30 & 49050 & 101000 & 2.15 & 22.30 \\
\hline & Standard deviation & 1260 & 1660 & 0.60 & & 1330 & 2800 & 1.58 & \\
\hline & Lower limit & 38050 & 73850 & 0.65 & & 44500 & 91400 & 0 & \\
\hline
\end{tabular}

Notes: (1) Specimens that broke in threads or in radius were considered no test.

(2) Malfunction in recorder system. No curve.

(3) Broke out of gage section.

(4) Dashes indicate not enough data for statistical treatment.

(5) Position of spectmens in plates is shown in $B-4$. 
TABLE I (cont)

PLATE 1

PLATE 2

\begin{tabular}{|c|c|c|c|c|c|c|c|c|c|}
\hline & & $\begin{array}{l}\text { Tensile } \\
\text { yield }\end{array}$ & $\begin{array}{l}\text { Tensile } \\
\text { ultimate }\end{array}$ & $\begin{array}{l}\text { Elongation, } \% \\
\text { in two inches }\end{array}$ & $\begin{array}{l}\text { Moduius } \\
\times 10^{6}\end{array}$ & $\begin{array}{c}\text { Tensile } \\
\text { yield }\end{array}$ & $\begin{array}{l}\text { Tensile } \\
\text { ultimate }\end{array}$ & $\begin{array}{l}\text { Elongation, } \\
\text { in two inches }\end{array}$ & $\begin{array}{l}\text { Moduius } \\
\times 10^{6}\end{array}$ \\
\hline Plate actial & Position in place & $c$ & $c$ & $c$ & C & $E$ & $E$ & $E$ & 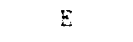 \\
\hline Transverse to rolling & Temperature of test & $76^{\circ} \mathrm{F}$ & $76^{\circ} \overline{\mathrm{F}}$ & $76^{\circ} \mathrm{F}$ & $76^{\circ} \mathrm{F}$ & $74^{\circ} \mathrm{F}$ & $74^{\circ} \mathrm{F}$ & $74^{\circ} \mathrm{F}$ & $74^{\circ} \mathrm{F}$ \\
\hline \multirow[t]{6}{*}{ Roon temperature } & Number of samples & $\tau(2)$ & 8 & 3 & 7 & $\delta$ & 8 & $5(3)$ & 8 \\
\hline & Minimm value & $42500-$ & $100000-$ & 9.5 & 18.20 & $48500-$ & 104000 & 7.0 & 20.00 \\
\hline & Maximm value & 47500 & 108000 & 17.0 & 22.80 & 54500 & 116000 & 10.5 & 27.00 \\
\hline & Mean & 44900 & 105000 & 13.90 & 20.40 & 51250 & 110000 & 8.00 & 23.90 \\
\hline & Standard deviation & 1830 & 5350 & 2.60 & & 2350 & 8700 & 1.40 & \\
\hline & Lower limit & 38650 & 87800 & 5.60 & & 43700 & 82000 & 2.10 & \\
\hline Plate material & Position in plate & $\mathrm{D}$ & D & $\mathrm{D}$ & $\mathrm{D}$ & $\mathrm{D}$ & $\mathrm{D}$ & $\mathrm{D}$ & $\mathrm{D}$ \\
\hline Parallel to rolling & Temperature of test & $76^{\circ} \mathrm{F}$ & $76^{\circ} \mathrm{F}$ & $76^{\circ} \mathrm{F}$ & $76^{\circ} \mathrm{F}$ & $72^{\circ} \mathrm{E}$ & $72^{\circ} \mathrm{F}$ & $72^{\circ} \mathrm{F}$ & $72^{\circ} \vec{F}$ \\
\hline \multirow[t]{6}{*}{ Room temperature } & Number of samples & 8 & 8 & 8 & 8 & $6(2)$ & 8 & 8 & 6 \\
\hline & Minimum value & $35200-$ & $109000-$ & 18.0 & 20.20 & $37700=$ & $118000-$ & 13.0 & 19.20 \\
\hline & Maximum value & 37500 & 112000 & 24.5 & 24.80 & 42200 & 129000 & 19.5 & 22.80 \\
\hline & Mean & 36500 & 110750 & 21.80 & 22.10 & 39300 & 123950 & 16.00 & 21.40 \\
\hline & Standard deviation & 1510 & 1045 & 2.35 & & 1650 & 8400 & 2.05 & \\
\hline & Lower limit & 31650 & 107400 & 14.20 & & 33200 & 97050 & 9.40 & \\
\hline Weld joint & Position in plate & B & B & B & B & $\mathrm{J}$ & $J$ & $J$ & $J$ \\
\hline Bars cut & Temperature of test & $72^{\circ} \mathrm{F}$ & $72^{\circ} \mathrm{F}$ & $72^{\circ} \mathrm{F}$ & $72^{\circ} \mathrm{F}$ & $73^{\circ} \mathrm{F}$ & $73^{\circ} \mathrm{F}$ & $73^{\circ} \mathrm{F}$ & $73^{\circ} \mathrm{F}$ \\
\hline \multirow[t]{6}{*}{ Transverse to joint } & Number of samples & $7(2)$ & 8 & 8 & 7 & $6(3)$ & 7 & 7 & 6 \\
\hline & Minimum value & $37800-$ & $88500-$ & 4.5 & 16.00 & $40500-$ & $98600-$ & 4.5 & 18.20 \\
\hline & Maximum value & 40500 & 95000 & 8.0 & 22.90 & 51000 & 100000 & 6.5 & 25.20 \\
\hline & Mean & 39150 & 91350 & 6.10 & 18.75 & 43200 & 99400 & 5.20 & 22.70 \\
\hline & Standard deviation & 1050 & 1960 & 1.10 & & 4350 & 645 & 0.90 & \\
\hline & Lower limit & 35550 & 85050 & 2.55 & & 26950 & 97200 & 2.05 & \\
\hline \multirow[t]{8}{*}{ Al1. weld metal } & Position in plate & A & $A$ & $A$ & A & A & A & A & A \\
\hline & Temperature of test & $69^{\circ} \mathrm{F}$ & $69^{\circ} \mathrm{F}$ & $69^{\circ} \mathrm{F}$ & $69^{\circ} \mathrm{F}$ & $69^{\circ} \mathrm{F}$ & $69^{\circ} \mathrm{F}$ & $69^{\circ} \mathrm{F}$ & $69^{\circ} \mathrm{F}$ \\
\hline & Number of samples & 5 & 5 & 5 & 5 & $4(2)$ & 4 & 5 & 5 \\
\hline & Minimum value & $52800-$ & $94200-$ & 7.0 & 18.50 & $53800-$ & $95600-$ & 5.0 & 20.50 \\
\hline & Maximum value & 53700 & 99200 & 9.0 & 21.00 & 56000 & 98200 & 7.0 & 23.20 \\
\hline & Mean & 53100 & 96400 & 8.20 & 19.50 & 55000 & 97450 & 6.00 & 21.45 \\
\hline & Standard deviation & 280 & 1890 & 0.85 & & 1020 & 1280 & 1.00 & \\
\hline & Lower limit & 51900 & 88400 & 4.60 & & 49700 & 90800 & 1.80 & \\
\hline
\end{tabular}


TABLE I (cont)

PLATE 1

PLATE 2

\begin{tabular}{|c|c|c|c|c|c|c|c|c|c|}
\hline & & $\begin{array}{l}\text { Tensile } \\
\text { yield }\end{array}$ & $\begin{array}{l}\text { Tensila } \\
\text { ultimate }\end{array}$ & $\begin{array}{l}\text { Elongation, } \% \\
\text { in two inches }\end{array}$ & $\begin{array}{l}\text { Modulus } \\
\times 10^{6}\end{array}$ & $\begin{array}{l}\text { Tensile } \\
\text { yield }\end{array}$ & $\begin{array}{l}\text { Tensile } \\
\text { ultimate }\end{array}$ & $\begin{array}{l}\text { Elongation, } \\
\text { in two inches }\end{array}$ & $\begin{array}{l}\text { Moduius } \\
\times 10^{6}\end{array}$ \\
\hline Plate material & Position in plate & E & $\varepsilon$ & E & $\varepsilon$ & $\boldsymbol{E}$ & $\boldsymbol{E}$ & $\varepsilon$ & E \\
\hline Transverse to rolling & Temperature of test & $350^{\circ} \mathrm{F}$ & $350^{\circ} \mathrm{F}$ & $350^{\circ} \mathrm{F}$ & $350^{\circ} \mathrm{F}$ & $350^{\circ} \mathrm{F}$ & $350^{\circ} \mathrm{F}$ & $350^{\circ} \mathrm{F}$ & $350^{\circ} \mathrm{F}$ \\
\hline \multirow[t]{6}{*}{ Elevated temperature } & Number of samples & $7(2)$ & 7 & 8 & 7 & 8 & 8 & 8 & 8 \\
\hline & Minimum value & $36000-$ & $55700-$ & 45.5 & 16.00 & $45200-$ & $68300-$ & 25.5 & 16.85 \\
\hline & Maximum value & 39000 & 67000 & 54.0 & 19.80 & 48700 & 72200 & 34.0 & 21.00 \\
\hline & Mean & 37500 & 62400 & 49.80 & 17.90 & 47000 & 70800 & 32.60 & 19.00 \\
\hline & Standard deviation & 2720 & 1560 & 3.35 & & 1240 & 1210 & 3.25 & \\
\hline & Lower limit & 28200 & 47050 & 39.00 & & 43000 & 66900 & 22.20 & \\
\hline Plate material & Position in plate & $\mathbf{F}$ & $\mathrm{F}$ & $\mathbf{F}$ & $\mathrm{F}$ & F & $\mathbf{F}$ & F & $\mathbf{F}$ \\
\hline Parallel to rolling & Temperature of test & $350^{\circ} \mathrm{F}$ & $350^{\circ} \mathrm{F}$ & $350^{\circ} \mathrm{F}$ & $350^{\circ} \mathrm{E}$ & $350^{\circ} \mathrm{F}$ & $350^{\circ} \mathrm{F}$ & $350^{\circ} \mathrm{F}$ & $350^{\circ} \mathrm{F}$ \\
\hline \multirow[t]{6}{*}{ Elevated temperature } & Number of samples & 8 & 8 & 8 & 8 & 8 & 8 & 8 & 8 \\
\hline & Minlmum value & $21500-$ & 59800 & 46.0 & 14.50 & 42000 & 73800 & 36.0 & 16.50 \\
\hline & Maximum value & 35700 & 66700 & 51.0 & 18.50 & 44200 & 77300 & 41.5 & 19.85 \\
\hline & Mean & 33000 & 64500 & 50.30 & 16.10 & 43100 & 74850 & 38.30 & 17.95 \\
\hline & Standard deviation & 4700 & 2700 & 2.10 & & 720 & 1420 & 2.30 & \\
\hline & Lower limit & 17900 & 55850 & 43.50 & & 40800 & 70300 & 31.00 & \\
\hline Weld joint & Position in plate & $\mathrm{J}$ & $\mathrm{J}$ & $\mathrm{J}$ & $\mathrm{J}$ & $\mathrm{J}$ & $\mathrm{J}$ & $\mathrm{J}$ & $J$ \\
\hline Bars cut & Temperature of test & $350^{\circ} \mathrm{F}$ & $350^{\circ} \mathrm{F}$ & $350^{\circ} \mathrm{F}$ & $350^{\circ} \mathrm{F}$ & $350^{\circ} \mathrm{F}$ & $350^{\circ} \mathrm{F}$ & $350^{\circ} \mathrm{F}$ & $350^{\circ} \mathrm{F}$ \\
\hline Transverse to joint & Number of samples & 8 & 8 & $4(3)$ & 8 & 8 & 8 & $7(3)$ & 8 \\
\hline \multirow[t]{5}{*}{ Elevated temperature } & Minimum value & $34000-$ & $62100-$ & 27.5 & 13.50 & $39700-$ & $73300-$ & 22.0 & 14.50 \\
\hline & Maximum value & 36500 & 71200 & 32.0 & 19.20 & 42500 & 77900 & 28.0 & 18.25 \\
\hline & Mean & 34500 & 66700 & 29.50 & 16.65 & 41400 & 75900 & 25.10 & 16.10 \\
\hline & Standard deviation & 2000 & 2660 & 1.95 & & 965 & .1250 & 2.05 & \\
\hline & Lower Iimit & 28050 & 58150 & 19.40 & & 38300 & 71900 & 18.10 & \\
\hline
\end{tabular}


TABLE I (cont)

PLATE 1

PLATE 2

\begin{tabular}{|c|c|c|c|c|c|c|c|c|c|}
\hline & . & $\begin{array}{l}\text { Tensile } \\
\text { yield }\end{array}$ & $\begin{array}{l}\text { Tensile } \\
\text { ultimate }\end{array}$ & $\begin{array}{l}\text { Elongation, } \% \\
\text { in two inches }\end{array}$ & $\begin{array}{l}\text { Modulus } \\
\times 10^{6}\end{array}$ & $\begin{array}{l}\text { Tensile } \\
\text { yield }\end{array}$ & $\begin{array}{l}\text { Tensile } \\
\text { ultimate }\end{array}$ & $\begin{array}{l}\text { Elongation, } \% \\
\text { in two inches }\end{array}$ & $\begin{array}{l}\text { Modulus } \\
\times 10^{6}\end{array}$ \\
\hline Plate material & Position in plate & E & $\mathbf{E}$ & E & $\mathrm{E}$ & $\mathrm{E}$ & E & E & E \\
\hline Transverse to rolling & Temperature of test & $500^{\circ} \mathrm{F}$ & $500^{\circ} \mathrm{F}$ & $500^{2} \mathrm{~F}$ & $500^{\circ} \mathrm{F}$ & $500^{\circ} \mathrm{F}$ & $500^{\circ} \mathrm{F}$ & $500^{*} \mathrm{~F}$ & $500^{\circ} \mathrm{F}$ \\
\hline \multirow[t]{6}{*}{ Elevated temperature } & Number of samples & 8 & 8 & 8 & 8 & 8 & 8 & 8 & 8 \\
\hline & Minimum value & $31100-$ & $41000-$ & 42.5 & 16.00 & $41000-$ & $52400-$ & 16.5 & 17.00 \\
\hline & Maxinum value & 32500 & 43200 & 53.0 & 18.50 & 45700 & 54700 & 27.0 & 18.15 \\
\hline & Mean & 31700 & 42100 & 47.80 & 17.20 & 44000 & 54100 & 24.10 & 17.40 \\
\hline & Standard deviation & 1090 & 2040 & 3.35 & & 1620 & 1050 & 4.10 & \\
\hline & Jower limit & 28200 & 35550 & 37.00 & & 38800 & 50800 & 11.00 & \\
\hline Plate material & Position in plate & $F$ & $\mathrm{~F}$ & $\mathrm{~F}$ & $\mathrm{~F}$ & $\mathrm{~F}$ & $\mathrm{~F}$ & $\mathbf{F}$ & $\mathrm{F}$ \\
\hline Parallel to rolling & Temperature of test & $500^{\circ} \mathrm{F}$ & $500^{\circ} \mathrm{F}$ & $500^{\circ} \mathrm{F}$ & $500^{\circ} \mathrm{F}$ & $500^{\circ} \mathrm{F}$ & $500^{\circ} \mathrm{F}$ & $500^{\circ} \mathrm{F}$ & $500^{\circ} \mathrm{F}$ \\
\hline \multirow[t]{6}{*}{ Elevated temperature } & Number of samples & $7(2)$ & 8 & 8 & 7 & 8 & 8 & 8 & 8 \\
\hline & Minimum value & $28200-$ & $38600-$ & 50.0 & 16.25 & $38700-$ & $53600-$ & 36.0 & 16.10 \\
\hline & Maximum value & 29500 & 40900 & 59.0 & 20.00 & 40500 & 58000 & 42.0 & 19.25 \\
\hline & Mean & 28750 & 40050 & 54.75 & 18.20 & 39700 & 55300 & 38.80 & 18.35 \\
\hline & Standard deviation & 425 & 885 & 3.00 & & 595 & 1280 & 2.10 & \\
\hline & Lower limit & 27300 & 37200 & 45.15 & & 37800 & 51200 & 32.00 & \\
\hline Weld joint & Position in plate & $\mathrm{J}$ & $\mathrm{J}$ & $\mathrm{J}$ & $\mathrm{J}$ & $\mathrm{J}$ & $\mathrm{J}$ & $J$ & J \\
\hline Bars cut & Temperature of test & $500^{\circ} \mathrm{F}$ & $500^{\circ} \mathrm{F}$ & $500^{\circ} \mathrm{F}$ & $500^{\circ} \mathrm{F}$ & $500^{\circ} \mathrm{F}$ & $500^{\circ} \mathrm{F}$ & $500^{\circ} \mathrm{F}$ & $500^{\circ} \mathrm{F}$ \\
\hline \multirow[t]{6}{*}{ Transverse to joint } & Number of samples & $7(2)$ & 8 & $2(3)$ & 7 & 8 & 8 & $7(3)$ & 7 \\
\hline & Minimum value & $30000-$ & $44300-$ & 23.0 & 13.50 & 24700 & 54300 & 18.0 & 12.85 \\
\hline & Maximum value & 33000 & 46600 & 23.50 & 18.20 & 40500 & 57200 & 25.0 & 14.75 \\
\hline & Mean & 31200 & 45400 & 23.20 & 16.50 & 37900 & 55600 & 22.20 & 14.50 \\
\hline & Standard deviation & 1025 & 795 & -- & & 5350 & 1250 & 2.45 & \\
\hline & Lower limit & 27700 & 42850 & $-\cdots$ & & 20700 & 51600 & 13.80 & \\
\hline
\end{tabular}


TABLE II

Charpy Impact Data

\begin{tabular}{|c|c|c|c|c|c|}
\hline \multicolumn{2}{|c|}{ Position in plate or weld } & \multicolumn{2}{|c|}{$\begin{array}{r}\text { Plate } 1 \\
\text { Sample No. (ft-1bs) }\end{array}$} & \multicolumn{2}{|c|}{$\begin{array}{r}\text { Plate } 2 \\
\text { Sample No. (ft-1bs) }\end{array}$} \\
\hline Bar & cut transverse to weld, & 1.H11 & 10.0 & $2 \mathrm{H} 11$ & 10.0 \\
\hline & notch in heat-affected & $1 \mathrm{H} 12$ & 10.0 & $2 \mathrm{H} 12$ & 9.0 \\
\hline & zone of parent metal & $1 \mathrm{H} 13$ & 9.0 & $2 \mathrm{H} 13$ & 10.0 \\
\hline & & Mean & 9.7 & Mean & 9.7 \\
\hline Bar & cut transverse to weld, & IH 21 & $-\cdots$ & $2 \mathrm{H} 2 \mathrm{I}$ & 12.5 \\
\hline & notch in weld metal and & $1 \mathrm{H} 22$ & 12.0 & $2 \mathrm{H} 22$ & 9.5 \\
\hline & parallel to main axis & $1 \mathrm{H} 23$ & 13.5 & $2 \mathrm{H} 23$ & 11.0 \\
\hline & of weld & Mean & 12.7 & Mean & 11.0 \\
\hline Bax & cut from weld, notch in & $1 \mathrm{H} 34$ & 12.0 & $2 \mathrm{H} 32$ & 10.5 \\
\hline & weld metal transverse to & $1 \mathrm{H} 35$ & 10.5 & $2 \mathrm{H} 33$ & 10.0 \\
\hline & maln axis of weld & $1 \mathrm{H} 36$ & 12.0 & $2 \mathrm{H} 34$ & 10.0 \\
\hline · & & Mean & 11.5 & Mean & 10.2 \\
\hline Bar & cut from plate, notch & $1 \mathrm{H} 42$ & 10.0 & $2 \mathrm{H} 41$ & 13.0 \\
\hline & parallel with direction & $1 \mathrm{H} 47$ & 10.0 & $2 \mathrm{H} 42$ & 12.5 \\
\hline & of rolling & $1 \mathrm{H} 49$ & 10.0 & $2 \mathrm{H} 43$ & 12.2 \\
\hline & & Mean & 10.0 & Mean & 12.6 \\
\hline Bar & cut from plate, notch & $1 \mathrm{H} 54$ & 12.5 & $2 \mathrm{H} 50$ & 22.0 \\
\hline & transverse to direction & $1 \mathrm{H} 55$ & 12.0 & $2 \mathrm{H} 54$ & 22.2 \\
\hline & of rolling & $1 \mathrm{H} 56$ & 12.0 & $2 \mathrm{H} 58$ & 18.2 \\
\hline & & Mean & 12.2 & Mean & 20.8 \\
\hline
\end{tabular}


TABLE IIT

Fillet Weld Shear

\begin{tabular}{|c|c|c|c|c|}
\hline & Specimen No. & & Total load & Location of fractures \\
\hline Longitudinal & $1 M 1-1$ & & 68500 & Weld first then butt strip \\
\hline Shear fillet we $1 \mathrm{ds}$ & $1 \mathrm{M} 1-2$ & & 65500 & Weld first then butt strip \\
\hline \multirow[t]{9}{*}{ Plate 1} & $1 M 1-3$ & & 67000 & Weld first then butt strip \\
\hline & $1 \mathrm{Ml}-4$ & & 66000 & In welds then butt strip \\
\hline & $1 M-5$ & & 78000 & In both butt strips \\
\hline & $1 M-6$ & & 77000 & In both butt strips \\
\hline & $1 M-7$ & & 74500 & Weld Eirst then butt strip \\
\hline & $1 M-8$ & & 72000 & In both butt strips \\
\hline & $1 \mathrm{M}-9$ & & 75000 & In both butt strips \\
\hline & & Mean & 71500 & \\
\hline & & & 67300 psi shear & \\
\hline \multirow[t]{11}{*}{ Plate 2} & $2 \mathrm{M} 2-1$ & & 65500 & Weld first then butt strip \\
\hline & $2 \mathrm{M} 2-2$ & & 67000 & Weld first then butt strip \\
\hline & $2 M 2-3$ & & 67250 & Weld first then butt strip \\
\hline & $2 M-4$ & & 67000 & In welds (a11 4) \\
\hline & $2 M-5$ & & 69500 & Weld first then plate \\
\hline & $2 M-6$ & & 57500 & In welds \\
\hline & $2 M-7$ & & 70000 & Weld first then plate \\
\hline & $2 \mathrm{M}-8$ & & 72500 & In plate \\
\hline & $2 M-9$ & & 43500 & In we $1 \mathrm{ds}$ \\
\hline & & Mean & 65000 & \\
\hline & & & 61100 psi shear & \\
\hline Trangueras shear & $1 L 1-1$ & & 86500 & In one weld and plate \\
\hline In fillet welds & $1 L 1-2$ & & 87750 & In one weld and plate \\
\hline \multirow[t]{8}{*}{ Plate 1} & $121-3$ & & 87500 & In welds \\
\hline & $1 L 1-4$ & & 86000 & In welds and plate \\
\hline & $1 L 1-5$ & & 85500 & In welds \\
\hline & $1 L 1-6$ & & 87000 & In welds \\
\hline & $1 L 1-7$ & & 77500 & In welds \\
\hline & $1 L 1-8$ & & 75500 & In welds and butt strip \\
\hline & & Mean & 84200 & \\
\hline & & & 63300 psi shear & \\
\hline \multirow[t]{11}{*}{ Plate 2} & $2 \mathrm{~L} 1-1$ & & 61500 & In welds \\
\hline & $2 L 1-2$ & & 57500 & In welds \\
\hline & $2 L 1-3$ & & 67500 & In welds \\
\hline & $2 L 1-4$ & & 66500 & In welds \\
\hline & $2 \mathrm{Ll}-5$ & & 67500 & In welds \\
\hline & $2 L l-6$ & & 59750 & In welds \\
\hline & $211-7$ & & 57500 & In welds \\
\hline & $2 L 1-8$ & & 63500 & In welds \\
\hline & $2 L 1-9$ & & 68000 & In welds \\
\hline & & Mean & 63250 & \\
\hline & & & $51500 \mathrm{psi}$ shear & \\
\hline
\end{tabular}




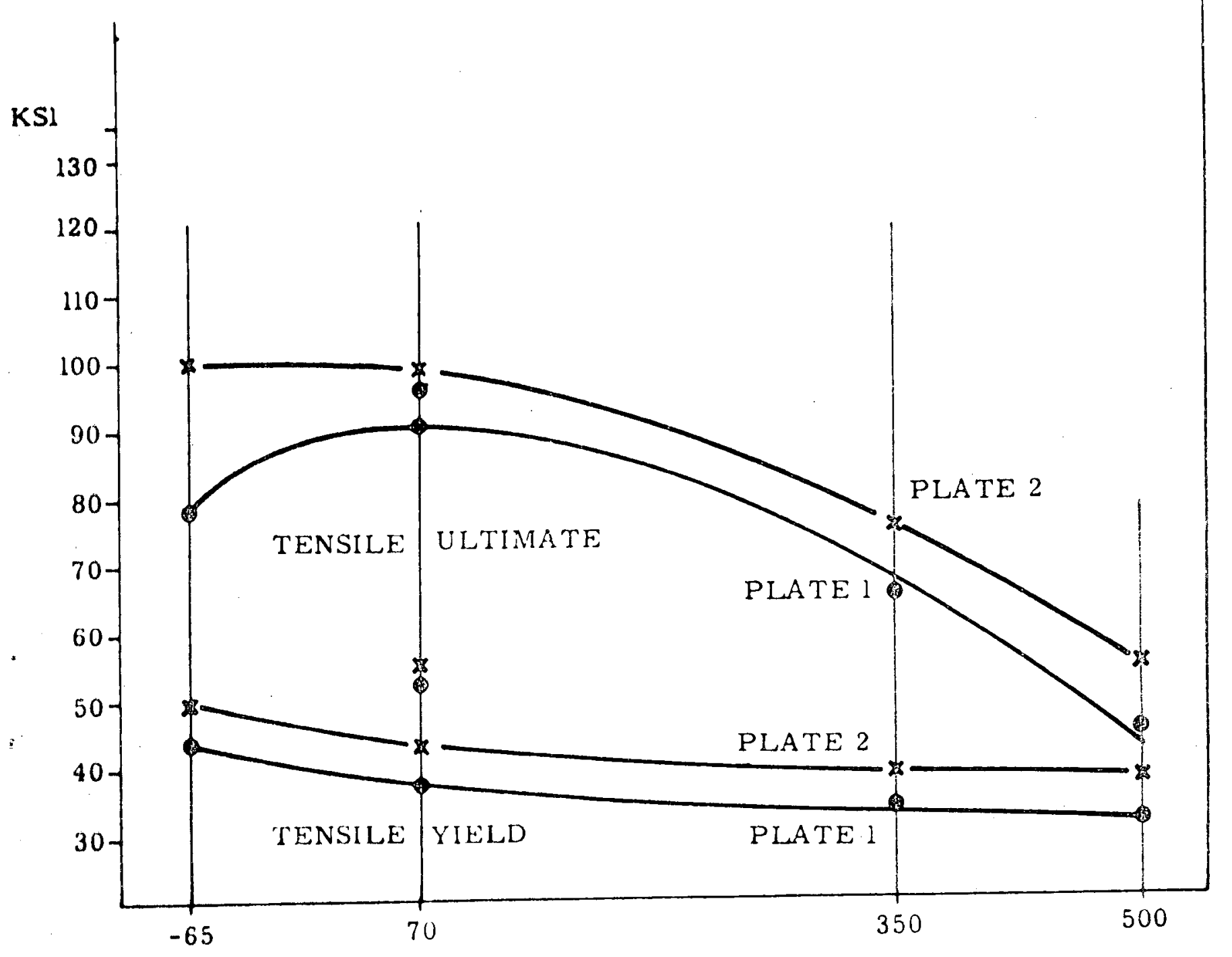

TEMPERATURE DEG. F

MEAN TENSILE VALUES VS. TEMP.

BUTT WELD JOINTS

Figure $B-1$ 


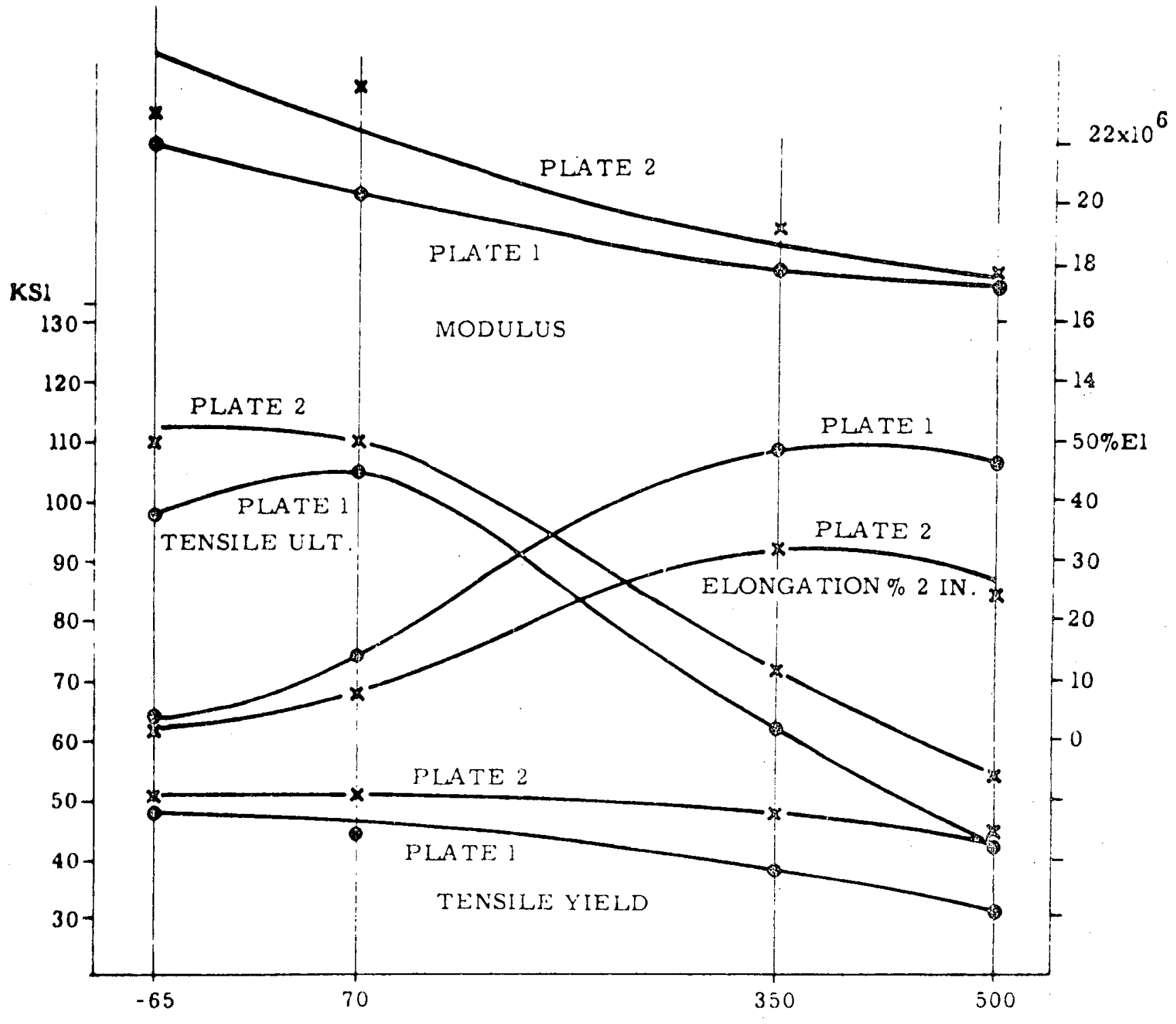

TEMPERATURE DEG. F

MEAN TENSILE VALUES VS. TEMP.

TRANSVERSE TO ROLLING

Figure $B-2$ 


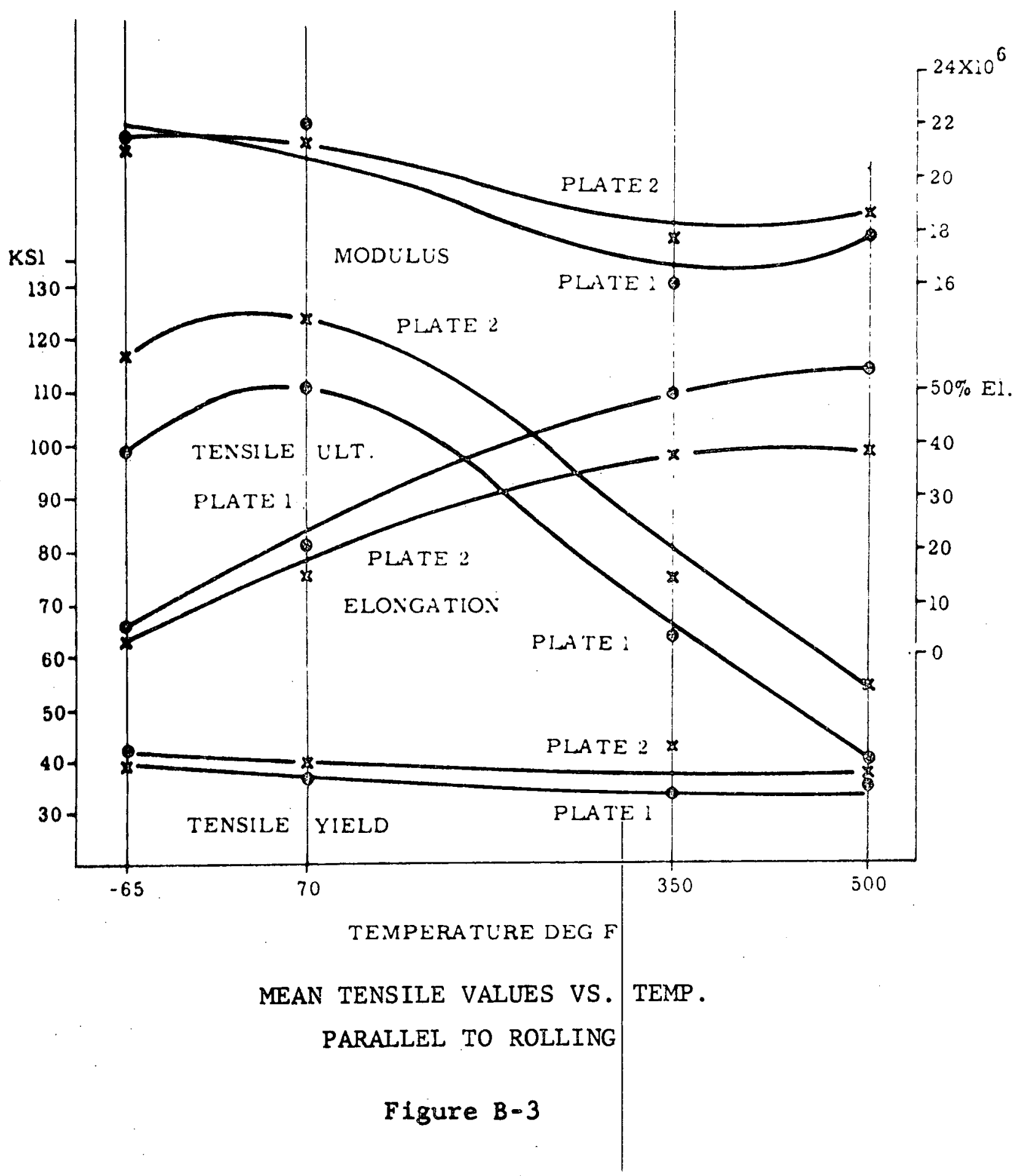




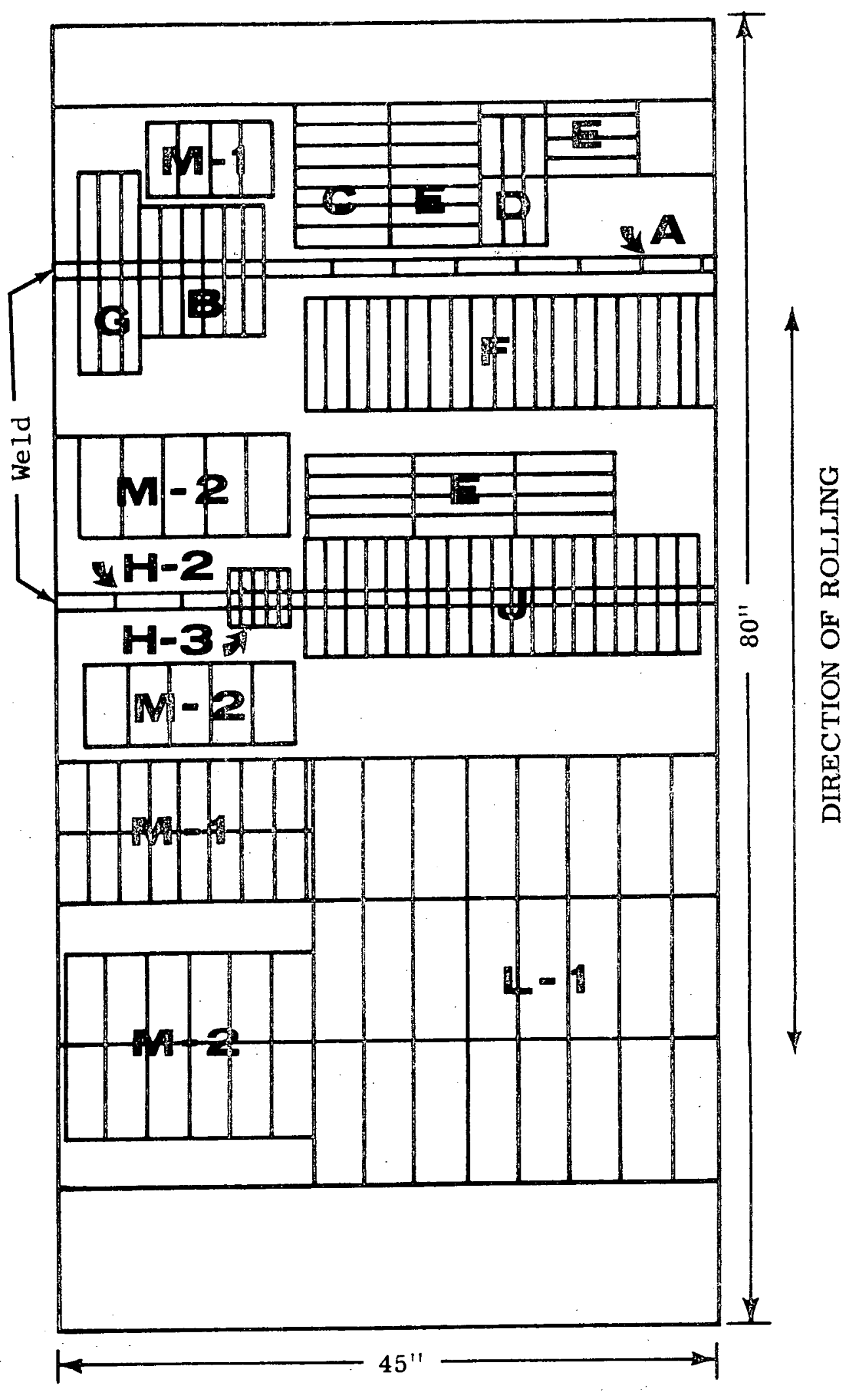

POSITION OF SPECIMENS IN PLATES

Figure $B-4$ 